University of Nebraska - Lincoln

DigitalCommons@University of Nebraska - Lincoln

8-2002

\title{
A Game Theory Approach to Deciding Who Will Supply Instream Flow Water
}

Ray Supalla

rsupalla1@unl.edu

Bettina Klaus

Osei Yeboah

Randall Bruins

Follow this and additional works at: https://digitalcommons.unl.edu/ageconfacpub

Part of the Agricultural and Resource Economics Commons

Supalla, Ray; Klaus, Bettina; Yeboah, Osei; and Bruins, Randall, "A Game Theory Approach to Deciding Who Will Supply Instream Flow Water" (2002). Faculty Publications: Agricultural Economics. 76.

https://digitalcommons.unl.edu/ageconfacpub/76

This Article is brought to you for free and open access by the Agricultural Economics Department at DigitalCommons@University of Nebraska - Lincoln. It has been accepted for inclusion in Faculty Publications: Agricultural Economics by an authorized administrator of DigitalCommons@University of Nebraska - Lincoln. 


\title{
A GAME THEORY APPROACH TO DECIDING WHO WILL SUPPLY INSTREAM FLOW WATER ${ }^{1}$
}

\author{
Raymond Supalla, Bettina Klaus, Osei Yeboah, and Randall Bruins ${ }^{2}$
}

\begin{abstract}
The resource management problem for the Middle Platte ecosystem is the insufficient water available to meet both instream ecological demands and out-of-stream economic needs. This problem of multiple interest groups competing for a limited resource is compounded by sharp disagreement in the scientific community over endangered species' needs for instream flows. In this study, game theory was used to address one dimension of this resource management problem. A sequential auction with repeated bidding was used to determine how much instream flow water each of three states - Colorado, Nebraska, and Wyoming - will provide and at what price. The results suggest that the use of auction mechanisms can improve the prospects for reaching a multi-state agreement on who will supply instream flow water, if the auction is structured to discourage misrepresentation of costs and if political compensation is allowed.

(KEY TERMS: environmental conflict resolution; game theory; water; economics; instream flow; endangered species.)
\end{abstract}

\section{INTRODUCTION}

The Platte River system consists of the North Platte and South Platte Rivers. The North Platte begins in North Central Colorado, passes through South Central Wyoming, crosses all of Nebraska, and joins the Missouri River at Omaha, Nebraska. The South Platte begins in East Central Colorado and joins the North Platte River at North Platte, Nebraska. The Platte system provides irrigation water to more than one million acres, supplies $300 \mathrm{MW}$ of hydroelectric power, supports more than two million visitor days of recreation each year, and provides critical habitat for fish and wildlife. The reach of the Platte River between Lexington and Grand Island, Nebraska, which is often called the Middle Platte or the Big Bend Reach, is especially important ecologically. It provides critical habitat for several protected species, including the Interior Least Tern, Piping Plover and Whooping Crane. The Middle Platte also serves as a migration staging area for thousands of Sandhill Cranes and each year is the site of an internationally acclaimed bird watching spectacle.

The different users of the Platte River system are aggressive competitors for the available water supplies and the riparian lands, resulting in considerable public controversy and extensive environmental and economic concern. Since 1976, the Nebraska Department of Water Resources (DWR) has held more than 400 days of public hearings to address five major proposed diversions and two instream flow rights for Platte River water. Since 1985, the public power districts in Nebraska have been in negotiations with the Federal Energy Regulatory Commission (FERC) and environmental interests over the relicensing of Lake McConaughy, a major storage reservoir on the North Platte River. From 1986 to 2001, the states of Wyoming and Nebraska were in litigation over the interstate allocation of Platte River water. This array of critical issues, as well as other factors, prompted the U.S. Environmental Protection Agency (USEPA) to select the Middle Platte in 1994 as one of five ecological risk assessment case studies that were considered nationally (USEPA, 1996).

At least a dozen stakeholder groups are involved with the Platte River management problem, when one considers combinations of geography and principal impacts of interest. Environmental interests in all

\footnotetext{
1Paper No. 01092 of the Journal of the American Water Resources Association. Discussions are open until February 1, 2003.

2Respectively, Professor and Assistant Professor, University of Nebraska-Lincoln, Department of Agricultural Economics, 307B Filley Hall, Lincoln, Nebraska 68583-0922; Post Doctorate, Auburn University, Department of Agricultural Economics, 203 Comer Hall, Auburn, Alabama 36849-5406; and Environmental Scientist, U.S. Environmental Protection Agency, 26 W. Martin Luther King Drive, Cincinnati, Ohio 45268 (E-Mail/Supalla: rsupalla@unl.edu).
} 
Supalla, Klaus, Yeboah, and Bruins

political jurisdictions (Colorado, Wyoming, Nebraska, and the U.S. Fish and Wildlife Service) have essentially the same objective - increased stream flow and management of riparian lands for endangered species protection. Irrigation interests are much more parochial between and within states. Upstream surface water irrigators want the right to continue irrigating and, in some instances, the right to develop additional acreage. Downstream surface water irrigators want their water supply protected against additional depletions from upstream irrigation or from environmental demands. All ground water irrigators in all locations want the right to pump at will, regardless of stream flow considerations. Hydropower interests want high reservoirs to maximize feet of head and would like to make reservoir releases during the summer months when electricity is worth the most. Coal fired electric utilities want assured cooling water supplies and expansion opportunities. Finally, recreation interests have mixed demands, including moderate reservoir storage levels, stream flows that sustain fishing and waterfowl hunting, and easy access to the river and to bird watching opportunities.

The central resource management problem is insufficient water available in the Platte system to meet all competing demands. This is most starkly indicated by the U.S. Fish and Wildlife Service (USFWS) claim that 417 thousand acre feet (kaf) per year of additional water is needed to meet endangered species needs for the Big Bend Reach. Endangered species requirements, as defined by the USFWS, essentially preclude any water consuming action that constitutes a federal nexus. This means that U.S. Forest Service leases in Colorado cannot be renewed, that Wyoming cannot pursue additional upstream water storage projects that would increase consumptive use, and that the public power districts in Nebraska cannot get a longterm hydropower license from FERC unless some accommodation of the competing demands can be made.

The problem of multiple interest groups competing for a limited resource is compounded by sharp disagreement in the scientific community over endangered species needs. Some scientists contend that very high stream flows are needed periodically to prevent vegetative growth on sandbars, thus sustaining the wide and shallow riverine habitat preferred by Whooping and Sandhill Cranes (Johnson,1996; Currier, 1995). Others contend that such scouring flows are of little value (Chadwick and Associates, 1994). There is also scientific disagreement regarding the amount of riverine habitat needed to sustain and enhance existing endangered species. Finally, some scientists suggest that riparian land management can substitute extensively for stream flow, while others are more skeptical (Habi Tech Inc., 1993).
The Platte River allocation problem is not very amenable to conventional institutional approaches. Allocations under the appropriations doctrine cannot be used to meet all endangered species needs because the river is already overappropriated. Markets theoretically could be used for reallocation, but the free rider problem discourages all potential purchasers from buying water to meet endangered species needs. Some potential purchasers hope to use the Endangered Species Act to force reallocation, while others are reluctant to pay unless all parties agree to an equitable sharing of the burden. This difficult institutional problem has led to several attempts to facilitate Platte River resource management decisions, including empirical modeling with and without stakeholder input, several negotiation formats, multi-state litigation, and, most recently, a Cooperative Agreement (CA) between the states and the U.S. Department of Interior (USDI) to take an interim adaptive management approach to the problem. However, none of these approaches has led to a comprehensive resource management plan that addresses the conflicting demands of competing interest groups. This paper explores the use of game theory as a resource management tool for addressing this problem.

Recent developments in game theory suggest that selected game theory techniques may be useful in resolving this type of resource management conflict. Game theoretic models allow economists to study the implications of rationality, self-interest, and equilibrium, both in market interactions that are modeled as games and in nonmarket interactions (Gibbons, 1997). Game theory has been occasionally applied to water resource management problems during the past decade. Becker and Easter (1995) used game theory to analyze the interdependency among eight states and two provinces concerning water diversions from the Great Lakes. Diversion decisions were modeled under different scenarios with different restrictions on the lakes where diversions could occur. This was done with combinations of states and provinces that totaled as many as ten players. The results suggested that states do not divert water necessarily because they stand to gain, but because they may lose more if they do not. In a case similar to the Middle Platte, Adams et al. (1996) proposed game theoretic models in the form of computer simulations to investigate the likely outcome of negotiations among agricultural water users, environmental groups, and municipal water users in California. Their results indicate that the outcome of the negotiation process depends crucially on the constitutional structure of the game, the input each group has in the decision making process, the coalitions of groups that can implement proposals, the scope of negotiations, and the outcome if parties fail to reach agreement. 
In this study we used an auction mechanism to model part of the decision process. The auction approach has particular merit for addressing who will supply instream flow water for the Middle Platte system and at what price. In particular, it provides a procedure for dealing with information asymmetries among the states. In an auction the parties reveal the price and preference information that is necessary for determining a water supply plan.

\section{PURPOSE AND OBJECTIVES}

The general purpose of this analysis was to investigate the use of game models for developing scientifically sound and politically feasible resource management plans for the Middle Platte ecosystem. A complete resource management plan for the ecosystem must address how much water to allocate to instream flows, which state should provide the water (Colorado, Nebraska, or Wyoming) and from what source (ground water irrigation rights, surface water irrigation rights, or conservation). It also must identify how the cost of instream flow water should be allocated among the states, the federal government, and the private sector. This paper focuses on which state should provide the water and at what price and addresses the problem within the context of the Cooperative Agreement signed in 1997 by Colorado, Nebraska, Wyoming, and the USDI.

\section{THEORY AND METHODOLOGY}

Who will provide and pay for the quantity of water allocated to environmental uses depends on the supply costs of the available options and on cost share, supply, and decision policies. Cost share policy concerns the distribution of costs among the three states and the USDI. There are several potential bases for determining cost shares, including payments based on out-of-stream consumptive use, the potential gains from improved environmental quality, or the relative economic value of the current water use regime. Supply policy concerns who should supply the water. Should it be supplied by the least cost suppliers irrespective of whether the supply burden falls disproportionately on one or more states, or, alternatively, should each state provide instream flow water in proportion to its contribution to consumptive use? Finally, who supplies the water and at what cost will depend on the decision policy (i.e., on the institutional arrangements for making and implementing supply decisions). In designing an auction model we seek an institutional procedure that addresses all of these aspects and results in allocating the desired quantity of water to environmental needs in an acceptable manner and at least cost.

The auction was designed as a second price, sequential auction with repeated bidding and predetermined cost shares. The only players are the three states. There is little need for involvement of environmental and agricultural interests, because their primary concern is the amount of reallocation, which is predetermined in the context of this analysis. The federal government has no further input to make once it commits to a given cost share. The auction is sequential in the sense that each state bids in a predetermined order to supply a given quantity of water, called a block. The bidding continues (repeats) until all parties except one (the low bidder) have passed. The block is then supplied by the low bidder at a price equal to the second lowest bid. Any number of blocks can be auctioned in this manner, thus tracing out a supply function. The predetermined cost shares define how much each state and the USDI contribute to the cash pool for purchasing environmental water. The state with the winning bid incurs an obligation to supply the water in return for a payment from the cash pool.

In mathematical terms, we consider a set of agents $N=\{1,2,3\}$, consisting of the three states: Colorado (1), Nebraska (2), and Wyoming (3). The Federal Government is a separate agent denoted by a subscript 4 and contributes a cost share, but it is not an active bidder. Cost shares are predetermined and can be depicted as $s_{1}, s_{2}, s_{3}$, and $s_{4}$. Hence, $0 \leq s_{1}, s_{2}, s_{3}, s_{4} \leq$ 1 and $s_{1}+s_{2}+s_{4}+s_{5}=1$. The cost functions for the states can be denoted by $C_{i}(q), i=1,2,3$, where the cost $C$ for any quantity $q$ consists of three components: acquisition cost, $A C$; third party cost, $T P$; and political compensation cost, $P C$. Hence, $C_{i}(q)=A C_{i}(q)$ $+T P_{i}(q)+P C_{i}(q)$ for all $q \geq 0 . A C_{i}(q)$ represents what the state will need to pay to acquire or produce the water, including administrative costs. $T P_{i}(q)$ represents the costs to the state that are incurred by parties not involved in the procurement decision or process. Both $A C_{i}(q)$ and $T P_{i}(q)$ are from prior analyses and are known by all players. The sum of $A C_{i}(q)$ and $T P_{i}(q)$ represents the real resource cost of supplying the water. $P C_{i}(q)$ represents an equity payment that the supplying party wants as compensation for the political difficulties inherent in reallocating water. $P C_{i}(q)$ is not known before the auction occurs. If $P C_{i}(q)$ were known, the state costs would be transparent, and for each given quantity $Q$ of water one could analytically solve for the cost minimizing quantities $q_{1}, q_{2}$, and $q_{3}$ of water from each state such that $Q=$ $q_{1}+q_{2}+q_{3}$. Because $P C_{i}(q)$ is unknown, however, the proposed auction model or some variant of it is 
Supalla, Klaus, Yeboah, and Bruins

necessary for getting the states to reveal the relevant cost information or supply preferences.

The states reveal their supply preferences when each block of water is auctioned by choosing to either supply the water or pay others to supply it. The way the auction works is that the winning bidder $j$ supplies the block of water at a cost $C_{j}(q)$ and receives a payment equal to the second lowest bid $B$, but this bidder also has to pay his predetermined cost share $s_{j} B$. Hence, the payoff from winning can be denoted as $P_{j}=\left(1-s_{j}\right) B-C_{j}(q)$. All $k$ players who do not win have to pay $B$ times $s_{k}$; hence, their payoffs are $P_{k}=-$ $s_{k} B$. Because in our case players who lose the auction incur a positive cost, the following equilibrium strategy dominates: all players bid until only the two lowest cost players remain; then the agent with the second lowest cost stops at his cost and the lowest cost player wins the auction with a bid equal (or slightly below) the second lowest cost. It is well known that for a sealed bid second price auction it is a dominant strategy for each player to announce costs truthfully (Klemperer, 1999). In our case, however, we use a descending English auction design that does not necessarily result in truthful revelation of all costs, but because repeated bidding is allowed, it does result in the same strategic outcome as the second price auction.

By auctioning successive blocks of water of some predetermined size one can develop the function $T C=$ $f(Q)$, which depicts how much it will cost the states and the USDI to supply varying quantities of instream flow water.

In Appendix A we prove that the described strategy profile is indeed a Nash equilibrium, because none of the players has an incentive to change his strategy.

\section{INPUT DATA}

Data requirements for the auction model included acquisition costs, third party costs, and political compensation costs. Acquisition costs represent the expected costs of increasing stream flow through supply augmentation, conservation, or purchasing or leasing of water from agriculture. Third party costs represent the economic value of the expected indirect effects on people who are not directly involved in providing the instream flow water. Political compensation (PC) costs are the payments above expected opportunity costs that the states may demand as compensation for the political turmoil associated with agreeing to supply a given quantity of water.

Acquisition costs were compiled from a recent report prepared by Boyle Engineering for use by the states and the USDI in resolving the Middle Platte management problem (Boyle Engineering Corporation, 1999). Estimated acquisition costs for water supplied by Colorado ranged from $\$ 115$ to $\$ 272$ per acre foot per year. Nebraska's costs were estimated at $\$ 72$ to $\$ 285$ and Wyoming's from $\$ 47$ to $\$ 224$ per acre foot. However, Nebraska was estimated to have 110 kaf available at less than $\$ 100$ per acre foot, whereas Wyoming had only $20 \mathrm{kaf}$ available at this cost and Colorado had none.

The estimated third party costs consisted primarily of the secondary effects from reduced irrigation activity, such as the reduced personal income of people engaged in supplying inputs or processing farm products. Third party costs were assumed to be 10 percent of acquisition costs based on historical levels of unemployment and underemployment and on regional input-output model results for the region (Jenkins and Konecny, 1999). This estimate reflects an assumption that a small amount of resources will remain underemployed over the long term as the economic base provided by irrigated agriculture declines. The estimate further assumes that there will be no offsetting increase in economic activity resulting from improved instream flows, because a change in stream flow that increases the population of endangered species is unlikely to induce any changes in economically significant activities such as recreation.

The concept of political compensation costs was incorporated in the auction game as a mechanism for reaching an agreement when all parties to the negotiation (auction) are both buyers and sellers. All parties can choose either to sell water to the group at a price that is equal to or greater than their real supply cost $(\mathrm{AC}+\mathrm{TP})$ or to pay their share of the cost of purchasing the water from someone else. If all parties (states) cared only about real supply costs, there would be no need for an auction, because the solution would necessarily consist of the least cost options irrespective of their location. Other considerations are reflected in the sales price, however, including risk and various political considerations. The difference between the real supply cost and the offer price is defined here as political compensation. These values can be estimated based on survey responses from state representatives and/or inferred from actual game results, if it becomes feasible to actually play the game. For purposes of this analysis, three PC cost scenarios were defined: zero, moderate, and high. They can be represented mathematically as

$$
\begin{aligned}
& \mathrm{PC}_{\mathrm{M}}=\mathrm{AC} \times 0.04 \times \mathrm{B}_{\mathrm{S}} \\
& \mathrm{PC}_{\mathrm{H}}=\mathrm{AC} \times 0.08 \times \mathrm{B}_{\mathrm{S}}
\end{aligned}
$$


where $\mathrm{PC}_{\mathrm{M}}$ and $\mathrm{PC}_{\mathrm{H}}=$ moderate and high political compensation cost, respectively; $\mathrm{AC}=$ water acquisition cost, \$/acre foot; and $\mathrm{B}_{\mathrm{s}}=$ number of $10 \mathrm{kaf}$ blocks of water supplied by state s. PC costs were assumed to escalate exponentially as the amount of water supplied by a single state increased, because political resistance to reallocating water from out-of-stream to instream uses is likely to increase as quantity increases.

\section{EMPIRICAL RESULTS}

The second price auction model was used to simulate who will supply instream flow water and at what cost, under the three assumed political compensation policies: no compensation, moderate, and high. The simulations further assumed a cost share policy consisting of Colorado 0.2, Nebraska 0.2, Wyoming 0.1, and the USDI 0.5. The rules of the auction required sequential bidding until two parties had passed, with minimum bid increments of $\$ 0.50$ per acre foot. Results were computed for water supply quantities ranging from 10 to $400 \mathrm{kaf}$ per year, although the welfare comparisons were calculated for only one quantity, 140 kaf. This quantity was chosen because it corresponds to the target quantity adopted by the states and the USDI under the terms of the Cooperative Agreement.

The water supply results show that under a no political compensation policy the costs are lowest, but Nebraska would need to supply 110 out of $140 \mathrm{kaf}$, or 79 percent of the water. Wyoming would supply $30 \mathrm{kaf}$ and Colorado none (Table 1). This suggests that some political compensation is likely to be necessary to reach a water supply agreement, because no player is likely to be willing to supply this much of the total instream flow requirement. The required compensation will emerge in the bid prices if a second-price auction is conducted or could be negotiated as a pricing policy. If the players behaved according to the moderate political compensation case, Nebraska would supply $100 \mathrm{kaf}$, Wyoming $40 \mathrm{kaf}$, and Colorado none, which is probably a more politically acceptable solution, but budget costs increase by 16 percent, or $\$ 2.5$ million per year, and welfare costs by 1.5 percent, or 0.2 million per year (Table 1). Under the high political compensation case, the water supply solution is still more likely to be acceptable at 80,40 , and 20 kaf for Nebraska, Wyoming, and Colorado, respectively, but budget costs have increased by 30 percent and welfare costs by 0.8 percent over the no compensation case. These findings reflect the fact that most of the low cost water is in Nebraska, and thus a water supply plan based on cost minimization is not likely to be politically acceptable. Under these circumstances, one would expect Nebraska to bid high in order to either get adequate political compensation or induce another player to supply the water, whichever comes first.

The use of a second price rather than a first price auction increases the budgetary cost of providing the water relative to the theoretical minimum. The theoretical minimum is the lowest price at which a given supplier is willing to supply a given quantity, including political compensation. The difference between the supplier's minimum price and the second lowest bid price constitutes an increased budgetary cost and a transfer of welfare to the supplying party from the other participants. At the 140 kaf level, budgetary costs were $16.3,9.0$, and 7.8 percent higher than the theoretical minimum for the zero, moderate, and high political compensation cases, respectively (Table 1). Although these numbers suggest that a second price auction increases budgetary costs significantly relative to the theoretical minimum, it is important to note that in a real world setting the minimum price remains unknown. A first price auction is an alternative that could lower budgetary costs, but because of the incentive to cheat, it may actually result in budgetary costs that exceed the second-price budgetary values, and there is no assurance that welfare costs will not be higher as well. Under a second price auction, one is at least assured that the dominant strategy will lead to a supply regime that minimizes total welfare costs.

In a first price auction, the bidders have an incentive to "cheat" by offering to supply water at a price above their minimum supply prices, hoping that another supplier will not underbid them. If this happens, true supply prices have not been revealed and buyers have paid more than the necessary supply costs. In a second price auction, however, all suppliers have an incentive to reveal their true supply prices, because the price they will receive if they win the bid is not their bid price, but rather the price of the next highest bidder. This ensures that total welfare costs are at a minimum, because the bidder with the minimum cost actually supplies the water, but the actual cash transfer, called a budgeted cost, may be higher by an amount equal to the difference between the winning bid and the next highest price.

Welfare costs represent the real cost of the water to all parties combined. Net welfare is equal to the budget cost less that part of the budget cost that represents transfer payments. Both the second price gain and the political compensation payments affect the distribution of welfare among the parties but do not affect total welfare because the loss to the paying party equals the gain to the receiving party. Net welfare is affected only by what economists call real resource costs, which in this case consist of water 
Supalla, Klaus, Yeboah, and Bruins

TABLE 1. Welfare Effects From Supplying 140 kaf of Environmental Water.

\begin{tabular}{|c|c|c|c|c|c|}
\hline \multicolumn{6}{|c|}{ Welfare Costs } \\
\hline Level of Political Compensation & Colorado & Nebraska & Wyoming & U.S. & Total \\
\hline \multicolumn{6}{|l|}{ None } \\
\hline Water Supplied (kaf) & 0 & 110 & 30 & 0 & 140 \\
\hline Budget Cost $(\$ / y r)$ & $-3,057,823$ & $-3,057,803$ & $-1,528,912$ & $-7,644,560$ & $-15,289,120$ \\
\hline Second Price Gain & 0 & $+1,772,443$ & $+360,652$ & 0 & $+2,133,095$ \\
\hline Political Compensation & 0 & 0 & 0 & 0 & 0 \\
\hline Net Welfare* & $-3,057,823$ & $-1,285,360$ & $-1,168,260$ & $-7,644,560$ & $-13,156,003$ \\
\hline \multicolumn{6}{|l|}{ Moderate } \\
\hline Water Supplied (kaf) & 0 & 100 & 40 & 0 & 140 \\
\hline Budget Cost $(\$ / y r)$ & $-3,552,900$ & $-3,552,900$ & $-1,776,450$ & $-8,882,250$ & $-17,764,500$ \\
\hline Second Price Gain & 0 & $+1,362,207$ & $+404,612$ & 0 & $+1,776,819$ \\
\hline Political Compensation & 0 & $+2,201,000$ & $+442,700$ & 0 & $+2,643,700$ \\
\hline Net Welfare & $3,552,900$ & $+10,307$ & $-929,138$ & $-8,882,250$ & $-13,353,981$ \\
\hline \multicolumn{6}{|l|}{ High } \\
\hline Water Supplied (kaf) & 20 & 80 & 40 & 0 & 140 \\
\hline Budget Cost ( $\$ / y r)$ & $-3,960,740$ & $-3,960,740$ & $-1,980,370$ & $-9,901,850$ & $-19,803,700$ \\
\hline Second Price Gain & $+111,191$ & $+867,424$ & $+469,561$ & 0 & $+1,448,176$ \\
\hline Political Compensation & $+372,900$ & $+2,881,100$ & $+889,500$ & 0 & $+4,143,500$ \\
\hline Net Welfare & $-3,476,649$ & $-212,216$ & $-621,309$ & $-9,901,850$ & $-14,212,024$ \\
\hline
\end{tabular}

*Welfare costs represent the real cost of the water to all parties combined. Net welfare is equal to the budget cost less that part of the budget cost which represents transfer payments. Both the second price gain and the political compensation payments affect the distribution of welfare among the parties but do not affect total welfare because the loss to the paying party equals the gain to the receiving party.

acquisition and third party costs. Hence, net welfare changes only if there is a change in who supplies the water and from what source.

The differences between the welfare costs and the budgetary costs for supplying 140 kaf of water under three different political compensation scenarios also suggest that the second price effect significantly changes the distribution of welfare costs (Table 1). Whereas, for example, Nebraska's share of the budget is 20 percent, the second price effect reduces its share of the welfare cost to only 8.4, 12.3, and 15.6 percent, respectively, for zero, moderate, and high political compensation. Essentially, Nebraska's gain from the second price effect goes down as its share of the total quantity supplied goes down.

The 140 kaf illustration shows that whereas total budget costs increased substantially with increases in political compensation, the welfare costs for all participants combined increased only slightly. This is because political compensation increases total welfare costs only if it results in someone with higher real costs supplying the water. If political compensation merely makes the same water supply plan politically acceptable, then there is a welfare distribution effect but no change in total welfare costs. The distribution effect is very large, however. For our illustrative case, Colorado and Nebraska both bore 20 percent of the budget cost, but their respective shares of the welfare cost were Colorado 23.2 and Nebraska 9.8 percent, with no political compensation, and Colorado 26.6 and Nebraska 0.0 percent when moderate compensation was assumed. These distributional effects result from the fact that water supply solutions have Nebraska supplying most of the water, while Colorado supplies very little, even when political compensation is substantial.

Another way of viewing the results is in terms of how much instream flow water could be supplied for a given budget under alternate political compensation policies. At a budget of, for example, $\$ 15$ million per year, it would be possible to supply $140 \mathrm{kaf}$ of water if no party demands political compensation, but only $100 \mathrm{kaf}$ if the high level of political compensation is used (Figure 1).

The total cost function for supplying environmental water with moderate political compensation was used 


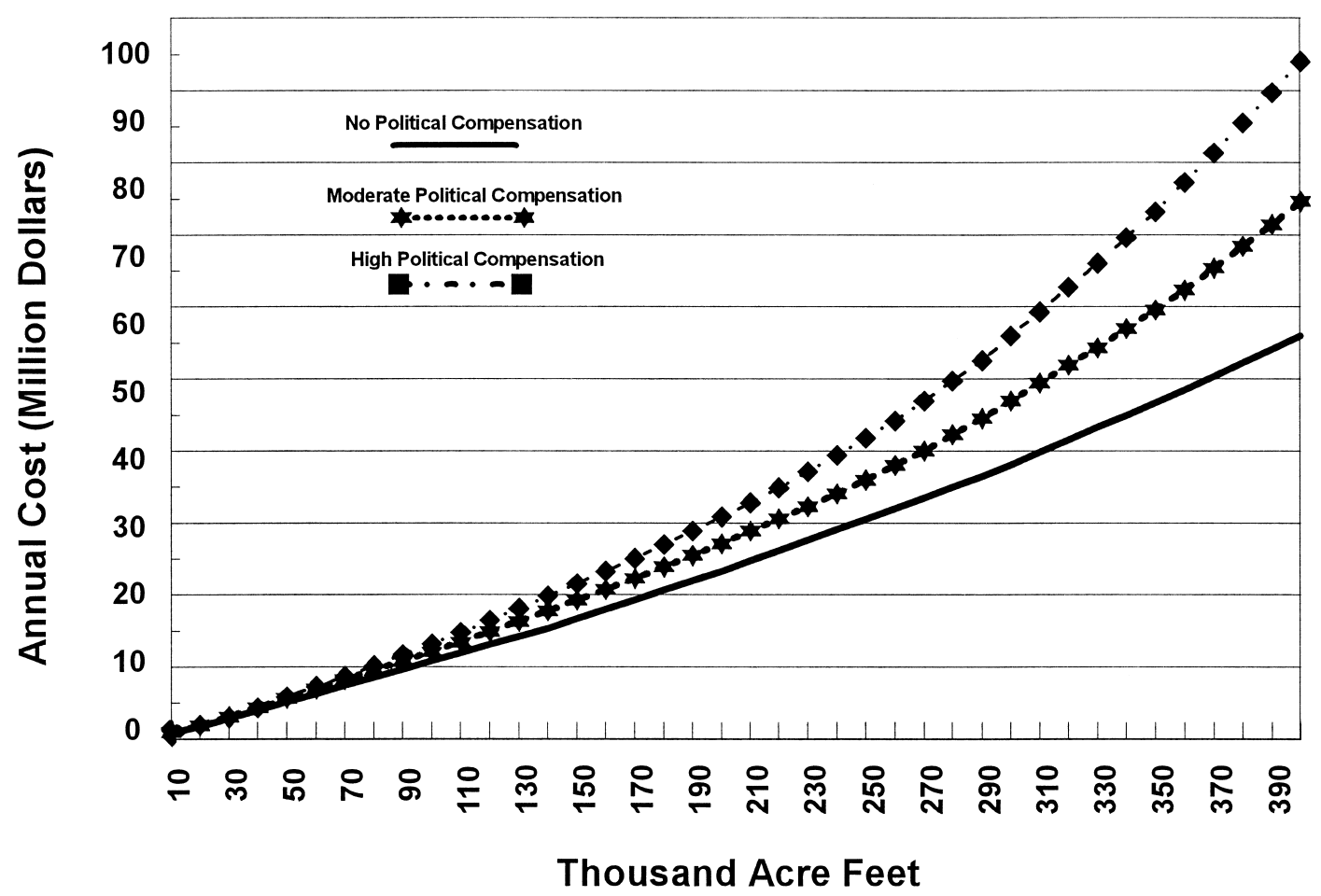

Figure 1. Total Budgeted Cost for Supplying Environmental Water Under Different Political Compensation Policies.

in later research as a partial basis for survey questions to determine reallocation policy preferences. It is clear from the shape of the cost functions that there are many options for finding a bargained solution to water reallocation. If there is no alternative to the moderate compensation supply function that is acceptable to all groups, it might be possible to shift the supply function to match an acceptable solution by persuading the supplying states to accept less political compensation.

\section{SUMMARY AND CONCLUSIONS}

Plans for management of the Middle Platte ecosystem have been mired in controversy for more than two decades. The central issue is how much water is needed to meet the needs of threatened and endangered species, who will supply the water, and at what price. The controversy has been intractable in part because of scientific disagreements and in part because the parties have been reluctant to potentially undercut their respective negotiating positions by revealing their true preferences. Some progress was made in 1997 with the signing of the Cooperative
Agreement. This agreement established an interim target of $140 \mathrm{kaf}$ in contrast to a USFWS request for $417 \mathrm{kaf}$, but it did not establish where the water was to come from and at what cost. This analysis proposes an auction approach for deciding who will supply the instream flow water for endangered species and at what price.

Simulation results suggest that a second price sequential auction would be an effective mechanism for getting potential suppliers to reveal their minimum prices for supplying different quantities of water. Actual costs depended on how much political compensation was required to induce individual states to supply the water rather than pay others to supply it. The theoretical minimum supply costs would occur if the parties were willing to reveal their minimum prices and if they did not demand a payment above real supply costs, called political compensation, in return for supplying the water. Simulated results assuming no political compensation showed one state supplying 79 percent of the water, a situation that is unlikely to be politically acceptable. Hence, two political compensation simulations were run that resulted in inducing a supply regime that is much more likely to be acceptable to all parties, albeit at much higher budgetary costs. 


\section{APPENDIX A. NASH EQUILIBRIUM}

We prove that the following strategy is a Nash Equilibrium: "all players bid until only the two lowest cost players remain; then the agent with the second lowest cost stops at his cost and the lowest cost player wins the auction with a bid equal (or slightly below) the second lowest cost."

We start with the winning player $j$. As long as player $j$ wins, his payoff is:

$$
P_{j}=\left(1-s_{j}\right) B-C_{j}(q)=\left(B-C_{j}(q)\right)-s_{j} B .
$$

The only way for player $j$ to change the outcome is to lose the auction. The only way for agent $j$ to lose is to stop bidding at a bid $B^{\prime} \geq B$. Then the second lowest cost player wins and receives a payment $B^{\prime \prime} \geq B$. Hence agent $j$ 's new payoff equals $P_{j}^{\prime}=-s_{j} B^{\prime \prime}$. However, $P_{j}^{\prime}=-s_{j} B^{\prime \prime} \leq-s_{j} B \leq\left(B-C_{j}(q)\right)-s_{j} B=P_{j}$. So, $P_{j} \geq P_{\mathrm{j}}^{\prime}$, which means that player $j$ will not be better off if he deviates from his original strategy.

Next, consider one of the losing players $k$. Since we assume that the winning player bids the second lowest costs (or slightly less), as long as player $k$ loses his payoff, is $P_{k}=-s_{k} B$. The only way to change the outcome for a nonwinning agent $k$ is to win the auction by bidding below his cost. If agent $k$ wins the auction, he will receive a payment of $B^{\prime} \leq B$. Hence agent $k$ 's new payoff equals $P_{k}^{\prime}=\left(1-s_{j}\right) B^{\prime}-C_{k}(q)$. However, $\left(1-s_{k}\right) B^{\prime}-C_{k}(q) \leq\left(1-s_{k}\right) B-C_{k}(q)=\left(B-C_{k}(q)\right)-s_{k} B$ $\leq-s_{k} B=P_{k}$. So, $P_{k} \geq P^{\prime}{ }_{k}$, which means that player $k$ will not profit if he deviates from his original strategy.

\section{ACKNOWLEDGMENTS}

The research reported here was supported by the U.S. Environmental Protection Agency, Project No. CR826987010 and by the Agricultural Research Division, Institute of Agriculture and Natural Resources, University of Nebraska-Lincoln (Journal Series No. 13784).

\section{LITERATURE CITED}

Adams, Gregory, Gordon Rausser, and Leo Simon, 1996. Modeling Multilateral Negotiations: An Application to California Water Policy. Journal of Economic Behavior and Organization 30:97111.

Becker, Nir and K. William Easter, 1995. Water Diversions in the Great Lakes Basin Analyzed in Game Theory Framework. Water Resources Management 9:221-242.

Boyle Engineering Corporation, 1999. Platte River Water Conservation/Supply Reconnaissance Study. Union, Colorado.
Chadwick and Associates, Inc. 1994. Forage Fish Monitoring Study, Central Platte River, Nebraska, 1993. Report Prepared for Nebraska Public Power District and the Central Nebraska Public Power and Irrigation District.

Currier, P. J., 1995. Woody Vegetation Expansion and Continuing Declines in Open Channel and Habitat on the Platte River in Nebraska. The Platte River Whooping Crane Critical Maintenance Trust, Grand Island, Nebraska.

Gibbons, Robert, 1997. An Introduction to Applicable Game Theory. Journal of Economic Perspectives 11(1):127-149.

Habi Tech, Inc., 1993. Hydrologic Components Influencing the Conditions of Wet Meadows Along the Central Platte River, Nebraska. Lincoln, Nebraska.

Jenkins, A. and R. Konecny, 1999. The Middle Platte Socioeconomic Baseline. University of Nebraska-Lincoln, Platte River Studies, Lincoln, Nebraska. Available at http://ianrwww.unl.edu/ianr/ pwp/products/pwpresources.htm.

Johnson, W. C., 1996. Channel Equilibrium in the Platte River, 1986-1995: Final Report. Department of Horticulture, Forestry, Landscape and Parks, South Dakota State University, Brookings, South Dakota.

Klemperer, Paul, 1999. Auction Theory: A Guide to the Literature. Journal of Economic Surveys 13(3):229-256.

U.S. Environmental Protection Agency (USEPA), 1996. Middle Platte River Floodplain: Ecological Risk Assessment and Problem Formulation. Draft 630/R-96/007a, Risk Assessment Forum, U.S. Environmental Protection Agency, Washington, D.C. 